\title{
OPTIMALISASI PERAN LEMBAGA AMIL ZAKAT DALAM KEHIDUPAN SOSIAL
}

\author{
Ramadhita \\ Program Studi al-Ahwal al-Syakhshiyah \\ Pascasarjana UIN Maulana Malik Ibrahim Malang \\ e-mail:dhita_rama@yahoo.com
}

\begin{abstract}
Abstrak
Zakat, infaq, shadaqah (ZIS) as funding sources in Islam, were not able to solve Indonesian muslim's sosio-econimic problem yet. According some studies, the potential amount of ZIS reached 100 bilion per year. This problems were caused by two factor, muzakki and amil. Muzakki still not trully believe in amil to distribute funds zakat, infaq, and shadaqah to mustahik. In other side, LAZ as frontier operator, was not optimal in digging and distributing the potential of zakat. To create public trust, LAZ has to optimize its functions, based on four basic prinsipals: the principle of faith, the moral principle, the principle of institutions, and principle menajemen .

Zakat, infaq, shadaqah sebagai sumber-sumber pendanaan sosial dipandang belum mampu menyelesaikan persoalan-persoalan sosio-ekonomi yang dihadapi masyarakat muslim di Indonesia. Padahal, berdasarkan sejumlah penelitian, potensi dana ZIS di Indonesia mencapai 100 miliyar lebih per tahunnya. Hal ini disebabkan oleh dua faktor, yaitu faktor muzakki dan faktor amil zakat. Muzakki belum percaya sepenuhnya terhadap amil, untuk mendistribusikan dana zakat, infaq, maupun shadaqah kepada mustahik. Selain itu, lembaga amil yang berperan sebagai operator, belum optimal dalam menggali dan mendayagunakan potensi zakat. Untuk menumbuhkan kepercayaan masyarakat terhadap LAZ, perlu dilakukan optimalisasi peran dan fungsi amil berdasarkan prinsip rukun iman, prinsip moral, prinsip lembaga, dan prinsip menajemen.
\end{abstract}

Kata Kunci: Lembaga Amil Zakat, Mustahik, Kesejahteraan

Islam merupakan agama yang menekankan keseimbangan dalam hidup. Melalui ajaran-ajarannya, Islam memberikan acuan, keyakinan, dan jalan hidup agar umat manusia mampu mengatasi persoalan-persoalan di dunia, serta mencapai kebahagiaan yang kekal di akhirat. ${ }^{1}$ Tidak hanya itu, ajaran Islam bergerak pada dua arah sekaligus, arah vertikal ( habl min Allâh) dan horizontal (habl min al-nâs). Atau dengan kata lain, ajaran-ajaran Islam tidak hanya mementingkan hubungan individu dengan Tuhannya (ta'abbudi), melainkan juga bersifat sosial kemasyarakatan (ijtima'iyyah). ${ }^{2}$

\section{Zakat dan Kesejahteraan Masyarakat}

Kesejahteraan menjadi salah satu prioritas utama umat Islam. Menurut M. Ali Hasan, pada dasarnya semua orang menginginkan kehidupan yang

\footnotetext{
1 Umratul Khasanah, Manajemen Zakat Modern Instrumen Pemberdayaan Ekonomi Umat (Malang: UIN-Malang Press,2010), h. 2

2 Fakhruddin, Fiqh dan Manajemen Zakat di Indonesia (Malang: UIN-Malang Press,2008), h. 193
}

layak dan terpenuhi kebutuhan pokoknya. Namun, kenyataannya tidak semua orang berkesempatan menikmati hal itu karena berbagai faktor, seperti tidak tersedianya lapangan pekerjaan, kemiskinan, atau rendahnya tingkat pendidikan. ${ }^{3}$ Melalui berbagai cara, Islam mencoba memberikan solusi sekaligus upaya preventif dalam menghadapi berbagai persoalan sosial dan ekonomi, seperti larangan menimbun kekayaan dan imbauan untuk berbagi.

Sumber-sumber keuangan Islam yang diperoleh dari zakat, infaq, dan shadaqah (ZIS) telah terbukti mensejahterakan umat bahkan menguatkan ekonomi negara. ${ }^{4}$ Contoh keberhasilan ZIS ini terlihat pada zaman pemerintahan khalifah Umar ibn Abdul Aziz, hanya dalam waktu sekitar dua tahun lima bulan masa pemerintahannya, program ZIS terbukti telah dapat menghilangkan kemiskinan di wilayah

\footnotetext{
3 M. Ali Hasan, Zakat dan Infak Salah Satu Solusi Mengatasi Problema Sosial di Indonesia (Jakarta: Kencana,2006), h. 1

4 Umratul Khasanah, Manajemen, h. 5
} 
yang dipimpinnya, dan bahkan kemudian hasil ZIS yang telah terkumpul, dikirim ke negara tetangga, khususnya Afrika Utara yang masih miskin. Bahkan, jauh sebelum itu, pada masa Rasulullah Saw. dan empat khalifah berikutnya (al-khulafâ' al-râshidûn) telah terbukti bahwa zakat mempunyai peran yang sangat penting sebagai sumber penerimaan negara dan sebagai alat untuk meningkatkan kesejahteraan umat. $^{5}$

Perhatian yang besar terhadap kesejahteraan umat, menurut Yusuf al-Qardhawi menunjukkan bahwa Islam memandang kemiskinan sebagai sesuatu yang membahayakan akidah, akhlak, akal sehat, keluarga dan masyarakat. Sebab, seseorang yang terjerat kesulitan ekonomi, pada umumnya menyimpan kedengkian terhadap orang yang kaya. Perasaan ini, menurut Imam al-Nawawi sebagaimana dikutip alQardhawi mampu melenyapkan kebaikan, memunculkan kehinaan, dan mendorong seseorang melakukan apapun untuk mencapai ambisinya. Dengan demikian, kemiskinan harus dianggap sebagai bencana dan segera ditanggulangi, salah satunya melalui pemberdayaan potensi ZIS. ${ }^{6}$

Potensi dana ZIS yang dapat dikumpulkan dan dikelola di Indonesia cukup besar. Dalam penelitian yang dilakukan oleh Center for the Studi of Religion and Culture (CSRC) ditemukan bahwa potensi zakat di Indonesia mencapai Rp. 19,3 triliun rupiah. ${ }^{7}$ Jumlah tersebut terdiri dari Rp. 5.1 triliun dalam bentuk barang dan Rp. 14.2 triliun sisanya adalah uang tunai. Sedangkan PIRAC (Public Interest Reseach and Advocacy Centre) menyebutkan bahwa potensi zakat di Indonesia tiap tahunnya berkisar antara 10 hingga 15 triliun rupiah. ${ }^{8}$ Bahkan menurut Direktur Toha Putra Center Semarang, H. Hasan Toha Putra MBA diperkirakan potensi zakat masyarakat Indonesia setiap tahunnya mencapai Rp. 100 triliun lebih. ${ }^{9}$ Penelitian terbaru tahun 2011, BAZNAS menyebutkan potensi zakat nasional Rp. 217 triliun, terdiri dari Rp. 82,7 triliun potensi zakat rumah tangga, Rp. 2,4 triliun

5 Multifiah, Peran Zakat, Infaq, dan Shadaqah terhadap Kesejahteraan Rumah Tangga Miskin, Jurnal Ilmu-Ilmu Sosial (Social Sciences), Volume 21 Nomor 1 (Februari,2009), h. 2

6 Yusuf al-Qardhawi, Dauru al-Zakat fi 'ilâj al-musykilât al-Istishâdiyah, terj. Sari Nurilita, Spektrum Zakat dalam Membangun Ekonomi Kerakyatan (Jakarta: Zikrul Hakim,2005), h. 24-25

7 Irfan Abubakar dan Chaider S. Bamualim, (ed.), Filantropi Islam dan Keadilan Sosial, Studi tentang Potensi, Tradisi dan Pemanfaatan Filantropi Islam di Indonesia, (Jakarta: Center for the Studi of Religion and Cultur, UIN Syarif Hidayatullah, 2006), h. 3

8 Noor Aflah, Arsitektur Zakat Indonesia Dilengkapi Kode Etik Amil Zakat Indonesia (Jakarta: UI-Press, 2009), h. 25

9 Abdul Ghofur Anshori, Hukum dan Pemberdayaan Zakat, (Yogyakarta: Pilar Media, 2006), h. 92. zakat BUMN, dan potensi zakat tabungan sebesar Rp. 17 triliun. $^{10}$

Potensi ZIS yang begitu besar per tahun, diharapkan mampu menanggulangi persoalan kemiskinan di Indonesia yang mencapai 29,89 juta orang (12,36 \%) dari jumlah penduduk Indonesia pada tahun 2011. ${ }^{11}$ Untuk mewujudkan hal ini, diperlukan kerjasama dari berbagai pihak, khususnya peran aktif dari institusi pengelola zakat. Sejak lahirnya Undang-Undang Nomor 38 Tahun 1999 tentang Pengelolaan Zakat, institusi pengelola zakat baik yang dibentuk oleh pemerintah atau swadaya masyarakat di tingkat pusat maupun daerah mulai bermunculkan dan mendapat legalitas dari negara. Menurut Imam Suprayogo, masyarakat Islam di Indonesia sesungguhnya tidak lagi kesulitan dalam menyalurkan zakat, infak, maupun shadaqahnya. Terlebih beberapa institusi pengelola zakat memiliki tenaga-tenaga volunteer yang bersedia menghitung berapa zakat yang harus dikeluarkan, mengambil dan mendistribusikannya kepada yang berhak menerima. Ironisnya, fenomena di atas belum berhasil mendorong umat Islam untuk mengeluarkan zakat. ${ }^{12}$

Potensi ZIS yang demikian besar belum terealisasi. Dana zakat yang dihimpun oleh institusi pengelola zakat di Indonesia masih sangat kecil. Menurut Didin Hafidhuddin, pada tahun 2008 dana yang terkumpul di Badan Amil Zakat Nasional (BAZNAS) baru 900 miliar. ${ }^{13}$ Pada Tahun 2011 saja, danaZIS yang berhasil dihimpun oleh BAZNAS hanya 39 miliar. $^{14}$ Yusuf Wibisono menyatakan bahwa perbandingan rata-rata pencapaian penghimpunan dana ZIS antara pendapatan Baznas dan LAZ adalah Rp 2 Miliar oleh masing-masing BAZ se-Indonesia (33 Baznas provinsi dan 502 Baznas kabupaten atau kota) dan Rp 15 miliar oleh setiap LAZ dalam setahun (18 Laznas dan 22 Lazda). Dengan perbandingan angka ini, Yusuf berhipotesis bahwa pengelolaan zakat oleh LAZ lebih unggul dibandingkan Baznas yang memiliki organ yang lebih banyak. ${ }^{15}$

\footnotetext{
10 Fakhruddin, "Rekontruksi Paradigma Zakat: Sebuah Ikhtiar Untuk Pemberdayaan Mustahiq", Makalah disampaikan dalam international guest lecture " Manajemen Zakat Kontemporer Malaysia-Indonesia, tanggal 10 Maret 2012 (Malang: Universitas Islam Negeri Maulana Malik Ibrahim Malang, 2012), h. 3

11 Badan Pusat Statistik, Jumlah Penduduk Miskin Indonesia (www.bps.go.id, diakses tanggal 17 Mei 2012)

12 Imam Suprayogo, Zakat, Modal Sosial, dan Pengentasan Kemiskinan, dalam Didin Hafidhuddin. dkk, The Power of Zakat Studi Perbandingan Pengelolaan Zakat Asia Tenggara (Malang: UIN-Malang Press, 2008), h. 5-6

13 Fakhruddin, Rekontruksi, h. 3

14 Badan Amil Zakat Nasional, Penerimaan dan Penyaluran Tahun 2011, (Online) (www.baznas.or.id, diakses tanggal 17 Mei 2012)

15 Yusuf Wibisono, Ironi Undang-Undang Zakat, (Online) (www.republika. co.id, diakses tanggal 17 Mei 2012)
} 
Terlepas dari perbedaan capaian dari masingmasing institusi, kedua institusi tersebut dirasa belum maksimal dalam menjalankan peran dan fungsinya dalam menggali potensi ZIS untuk meningkatkan kesejahteraan muzakki diIndonesia. Gagasaninimencoba membidik salah satu institusi pengelola zakat, yaitu Lembaga Amil Zakat (LAZ) untuk ditinjau peran dan fungsinya, serta bagaimana mengoptimalkan kinerja LAZ dalam menjalankan fungsi sosial. Persoalan ini diangkat dengan pertimbangan, institusi inilah yang terbentuk atas dasar kesadaran masyarakat (community consciousness) akan urgensi zakat dalam mengatasi persoalan sosial ekonomi di Indonesia.

\section{Eksistensi Lembaga Amil Zakat di Indonesia}

Pengelolaan zakat menurut Undang-Undang Nomor 23 Tahun 2011 adalah kegiatan perencanaan, pelaksanaan, dan pengoordinasian pengawasan dalam pengumpulan, pendistribusian, dan pendayagunaan zakat. Kegiatan-kegiatan tersebut, salah satunya Lembaga Amil Zakat sebagaimana diatur dalam Pasal 17 Undang-Undang Nomor 23 Tahun 2011 tentang Pengelolaan Zakat.

Menurut Sudirman, Lembaga Amil Zakat merupakan institusi pengelola zakat yang dibentuk oleh masyarakat sehingga tidak memiliki afiliasi dengan Badan Amil Zakat, ${ }^{16}$ yang notabene dibentuk atas prakarsa pemerintah. Secara yuridis, definisi LAZ dapat ditemukan dalam penjelasan Pasal 7 Ayat (1) Undang-Undang Nomor 38 Tahun 1999 tentang Pengelolaan Zakat. Lembaga amil zakat dipandang sebagai institusi pengelolaan zakat yang sepenuhnya dibentuk atas prakarsa masyarakat dan oleh masyarakat. ${ }^{17}$

Setelah Undang-Undang ini diubah, definisi LAZ turut mengalami perubahan sebagaimana diatur dalam Pasal 1 poin 8 Undang-Undang Nomor 23 Tahun 2011 tentang Pengelolaan Zakat. Lembaga Amil Zakat yang selanjutnya disingkat LAZ adalah lembaga yang dibentuk masyarakat yang memiliki tugas membantu pengumpulan, pendistribusian, dan pendayagunaan zakat. ${ }^{18}$ Melalui definisi ini, peran yang dimainkan oleh LAZ turut berubah, yaitu sebagai pembantu dalam pengelolaan zakat di Indonesia.

Perkembangan LAZ sebagai institusi pengelola zakat, infaq dan shadaqah di Indonesia, dapat dibagi

\footnotetext{
16 Sudirman, Zakat dalam Pusaran Arus Modernitas (Malang: UIN-Malang Press, 2007), h. 99

17 Undang-Undang Nomor 38 Tahun 1999 tentang Pengelolaan Zakat Lembaran Negara Tahun 1999 Nomor 164 Tambahan Lembaran Negara Nomor 3885

18 Undang-Undang Nomor 23 Tahun 2011 tentang Pengelolaan Zakat Lembaran Negara Tahun 2011 Nomor 115
}

menjadi tiga periode: Pertama, Sebelum Lahirnya Undang-Undang Nomor 38 Tahun 1999 tentang Pengelolaan Zakat. Pengumpulan dan pendistribusian zakat telah dilakukan sejak Islam masuk ke Nusantara. Pada masa penjajahan Belanda, pelaksanaan ajaran agama Islam termasuk zakat diatur dalam Ordonantie Pemerintah Hindia Belanda Nomor 6200 tanggal 28 Februari 1905. Dalam pengaturan ini pemerintah tidak mencampuri masalah pengelolaan zakat dan menyerahkan sepenuhnya kepada umat Islam.

Pada awal kemerdekaan pengelolaan zakat masih diserahkan pada masyarakat. Baru pada tanggal 8 Desember 1951, Kementerian Agama mengeluarkan Surat Edaran Nomor: A/VII/17367 tentang Pelaksanaan Zakat Fitrah, yang intinya pemerintah mendorong masyarakat secara aktif mengawasi pendistribusian zakat agar sesuai dengan hukum Islam. Dengan demikian, pemungutan dan pendistribusian zakat belum dilakukan oleh sebuah lembaga dan masih bersifat sporadis. Pada tahun 1968, muncul dua institusi yang berhubungan erat dengan pengelolan zakat, yaitu Badan Amil Zakat (BAZ) melalui Peraturan Menteri Agama (PMA) Nomor 4 Tahun 1968 dan bait al-mâl yang diatur dalam Peraturan Menteri Agama Nomor 5 Tahun 1968. Berdasarkan dua PMA ini Bait al-mâl berfungsi sebagai penerima dan penampung zakat, dan kemudian dikumpulkan kepada Badan Amil Zakat untuk didistribusikan kepada mustahiq. Bait al-mâl yang dimaksud dalam PMA Nomor 4 Tahun 1968 berstatus yayasan dan bersifat semi resmi. ${ }^{19}$ Dua peraturan ini memberikan peluang lahirnya sejumlah Lembaga Amil Zakat di Indonesia seperti Yayasan Baitul Mal Umat Islam Bank Negara Indonesia (BAMUIS BNI) pada tanggal 5 Oktober 1967 di Jakarta, Yayasan Dana Sosial alFalah (YDSF) pada tanggal 1 Maret 1987 di Surabaya, dan Dompet Dhuafa Republika pada 14 September 1994 di Jakarta.

Kedua, Pasca Lahirnya Undang-Undang Nomor 38 Tahun 1999 tentang Pengelolaan Zakat. Hukum Islam semakin mendapatkan tempat dalam proses legislasi setelah dilakukan reformasi. Pada tahun 1999, Pemerintah beserta DPR mengesahkan Undang-Undang Nomor 38 tentang Pengelolaan Zakat, dengan peraturan pelaksana berupa Keputusan Menteri Agama Nomor 581 Tahun 1999 jo. Keputusan Menteri Agama Republik Indonesia Nomor 373 Tahun 2003 tentang Pelaksanaan Undang-Undang Nomor 38 Tahun 1999 dan Keputusan Direktur Jendral Bimas

19 Fakhruddin, Figh, h. 244-245 
Islam dan Urusan Haji Nomor D-291 Tahun 2000. ${ }^{20}$ Melalui Undang-Undang ini, keberadaan Lembaga Amil Zakat (LAZ) yang dibentuk dan dikelola oleh masyarakat, yang terhimpun dalam berbagai organisasi masyarakat (ormas), yayasan, atau institusi lainnya diakui dan mendapat perlindungan hukum, dengan catatan harus dikukuhkan terlebih dahulu oleh pemerintah. Sebagaimana dalam Pasal 21 ayat (1) Keputusan Menteri Agama Republik Indonesia Nomor 373 Tahun 2003 Tentang Pelaksanaan UndangUndang Nomor 38 Tahun 1999 Tentang Pengelolaan Zakat.

Menarik untuk dicermati, dalam Pasal 22 dinyatakan bahwa yang dapat mengajukan diri sebagai LAZ adalah organisasi Islam dan atau Lembaga Dakwah yang bergerak di bidang dakwah, pendidikan, sosial dan kemaslahatan umat Islam, dengan persyaratan: (1) Berbadan hukum; (2) Memiliki data muzakki dan mustahiq; (3) Telah beroperasi minimal selama 2 tahun; (4) Memiliki laporan keuangan yang telah diaudit oleh akuntan publik selama 2 tahun terakhir; (5) Memiliki wilayah operasi secara nasional minimal 10 provinsi untuk LAZNAS dan memiliki wilayah operasional minimal $40 \%$ dari jumlah Kabupaten/Kota di Propinsi untuk LAZDA; (5) Mendapat rekomendasi dari Forum Zakat (FOZ); (6) Telah mampu mengumpulkan dana minimal Rp. 500.000.000, untuk LAZDA dan Rp. 1.000.000.000 untuk LAZNAS dalam satu tahun; (7) Melampirkan surat pernyataan bersedia disurvei oleh Tim yang dibentuk oleh Departemen Agama dan diaudit oleh akuntan publik; dan terakhir dalam melaksanakan kegiatan bersedia berkoordinasi dengan BAZNAS, BAZDA dan Departemen Agama.

Di antara LAZ yang didirikan pasca berlakunya Undang-Undang Nomor 38 Tahun 1999 antara lain Baitul Maal Muamalat yang didirikan oleh Bank Muamalat Indonesia pada tanggal 16 Juni 2000. Yayasan Baitul Maal Bank Rakyat Indonesia pada tanggal 10 Agustus 2001. Lembaga Amil Zakat Infaq Shadaqah Muhamadiyah (LAZISMU) yang didirikan oleh PP. Muhamadiyah Pada Tahun 2002. Pasca lahirnya Undang-Undang Nomor 38 Tahun 1999, tidak terdapat perbedaan signifikan peran dan fungsi institusi pengelola zakat. Amil zakat, baik BAZ maupun LAZ tidak memiliki otoritas memaksa agar seseorang membayar zakat. Para wajib zakat tidak didaftar dan diatur oleh pemerintah, seperti halnya para wajib pajak. Undang-Undang inipun juga tidak

20 Fakhruddin, Fiqh, h. 247 mencantumkan sanksi bagi orang-orang yang tidak mau melaksanakan zakat. Sehingga potensi zakat belum dapat didayagunakan secara maksimal.

Ketiga, Pasca berlakunya Undang-Undang Nomor 23 Tahun 2011 tentang Pengelolaan Zakat. Selama 12 tahun setelah berlakunya Undang-Undang Nomor 38 Tahun 1999 tentang Pengelolaan Zakat, tidak sedikit persoalan yang muncul dalam proses pengumpulan, pendayagunaan, dan pendistribusian zakat. Undang-Undang ini dinilai memiliki banyak kekurangan dan amat ringkas. Selain itu, UndangUndang ini hanya menyebutkan peraturan menteri sebagai aturan pelaksana. Berdasarkan hal ini, pada tahun 2007 Forum Zakat dan BAZNAS menyusun konsep amandemen Undang-undang Pengelolaan Zakat dan diajukan ke DPR.

Menurut Ahmad Juwaini, ada tiga isu sentral yang diusung dalam draft revisi Undang-Undang Pengelolaan Zakat : Pertama, adanya sanksi bagi muzakki yang ingkar, baik sanksi administrasi maupun sanksi finansial; Kedua, Penataan organisasi pengelola zakat dan pemisahan fungsi regulator atau pengawas, operator dan kordinator; Ketiga, menjadikan Zakat sebagai pengurang pajak. ${ }^{21}$ Noor Aflah mengatakan bahwa organisasi pengelola zakat di Indonesia tidak memiliki struktur pengendalian yang jelas. Dalam Undang-Undang Nomor 38 Tahun 1999 hanya mengatur mengenai operator yang bertugas menghimpun dan mendistribusikan zakat, tanpa ada lembaga pengawas. Akibatnya, sering terjadi tumpang tindih yang memicu distrust terhadap LAZ. Dalam RUU Pengelolaan Zakat, BAZNAS diposisikan sebagai regulator teknis dan pengawas bagi seluruh lembaga amil zakat di Indonesia, seperti peran Bank Indonesia dalam dunia perbankan. Setidaknya ada dua sebab perubahan posisi ini, (1) fungsi pengawasan yang dilakukan Kementerian Agama dipandang tidak efektif, karena banyaknya tugas dan tanggungjawab yang diembannya. (2) Lembaga ini merupakan satusatunya lembaga yang dibentuk melalui Keputusan Presiden. ${ }^{22}$

Dalam proses pembahasan Rancangan UndangUndang Pengelolaan Zakat yang baru, pemerintah sempat mewacanakan penggabungan antara LAZ dengan BAZ. Padahal banyak LAZ yang muncul lebih dahulu sebelum Undang-Undang Pengelolaan Zakat. Dalam catatan Noor Aflah, setidaknya terdapat

\footnotetext{
21 Ahmad Juwaini, Mencermati dan Menyikapi Undang-Undang Nomor 23 Tahun 2011, (Online) (www.forumzakat.net, diakses tanggal 18 Mei 2012) 22 Noor Aflah, Arsitektur, h. 2-4
} 
tiga pandangan yang berbeda: ${ }^{23}$ Pertama, Pandangan yang menolak penggabungan. Hamy Wahjunianto - mantan ketua umum Forum Zakat - menyatakan bahwa LAZ merupakan bentuk partisipasi positif masyarakat yang perlu didukung, bukan sebaliknya. Publik lebih percaya kepada LAZ daripada BAZ dalam menyalurkan zakat, infak, atau shadaqahnya. Hal ini terbukti dari capaian dana yang diperoleh LAZ jauh lebih besar dari dana yang dikelola BAZ. Jumlah donatur dan muzakki yang menjalin kemitraan dengan LAZ juga semakin bertambah. Jika LAZ dan BAZ digabung apakah pemerintah menjamin bahwa para donatur dan muzakki mau menyalurkan ZIS kepada BAZ. Optimalisasi fungsi pengelolaan zakat bukan dengan menggabungkan dua lembaga tersebut. Melainkan memberikan ruang gerak yang luas bagi LAZ untuk menjalankan fungsinya. Penggabungan bisa dilakukan setelah terbentuk lembaga pengawas pengeloaan zakat dan adanya standarisasi mutu lembaga zakat.

Kedua, pendapat yang mengharuskan penggabungan. Kelompok ini diwakili oleh Mukhtar Zarkasyi dari Kementerian Agama, yang menyatakan bahwa sejak awal pengelolaan zakat di Indonesia diarahkan hanya dikelola oleh Badan Amil Zakat sebagai lembaga remi yang dibentuk oleh pemerintah. Tujuannya, agar pengumpulan, pendistribusian, dan pendayagunaannya dapat berjalan dengan efektif, efisien, dan dapat mewujudkan kesejahteraan sosial sebagaimana amanat UUD RI 1945. LAZ yang dikehendaki Undang-Undang hanyalah LAZ yang berasal dari ormas-ormas Islam. Banyaknya LAZ saat ini sebenanya tidak sesuai dengan amanat Undang-Undang. Ironisnya, menurut Mukhtar justru dikukuhkan oleh Menteri Agama.

Ketiga. Pandangan yang moderat seperti yang disampaikan Didin Hafidhuddin. Penyatukan BAZ dan LAZ yang diwacanakan pemerintah pasti bertujuan baik, namun idealnya pengelolaan zakat di Indonesia ke depan tetap harus mengakomodasi keberadaan BAZ dan LAZ. Sebab, melalui LAZ muncul kesadaran dari masyarakat untuk membayar Zakat. Sedangkan BAZ memiliki kekuatan yang mengikat. Akan tetapi, harus ada pembagian peran di antara keduanya. BAZ yang mewakili pemerintah diproyeksikan sebagai regulator dan LAZ sebagai cerminan keterlibatan masyarakat juga dihargai keberadaannya. Meskipun demikian, program-program LAZ harus diawasi sehingga tidak berjalan sendiri-sendiri, bahkan rebutan wilayah

23 Noor Aflah, Arsitektur, h. 13-22 garapan. Kepengurusan BAZ juga harus melihatkan masyarakat. Sehingga potensi zakat dapat digali secara optimal.

Kekhawatiran Hamy Wahjunianto, tidak dapat disalahkan sepenuhnya. Jika melihat fenomena yang ada, masyarakat cenderung tidak percaya terhadap kinerja lembaga-lembaga bentukan pemerintah, terlebih untuk mengelola asset ZIS yang demikian besar. Berdasarkan track record selama ini, sumber-sumber keuangan yang dikelola oleh negara, dijadikan lahan korupsi oleh oknum-oknum pejabat negara, dan tidak menutup kemungkinan asset ZIS juga bernasib sama. Masyarakat miskin yang seharusnya diberdayakan tetap dibiarkan miskin, meskipun mendapat bagian zakat, infaq, maupun shadaqah. Dana ZIS yang didistribusikan kepada para mustahik hanya sekedar formalitas menjalankan perintah Undang-Undang, tanpa memberikan cara pengelolaan agar dana tersebut tetap mengalir dan merubah mereka menjadi muzakki suatu saat nanti. Banyaknya LAZ yang berlombalomba mengumpulkan dana ZIS juga memimbulkan berbagai persoalan. Misalnya, satu orang muzakki atau donatur menjadi sumber dana dari beberapa LAZ sehingga memberatkan muzakki. Selain itu, ada kecenderungan masing-masing LAZ mementingkan institusinya sendiri dalam upaya mensejahtrakan masyarakat kurang mampu, sekalipun ada lembaga bersama seperti Forum Zakat (FOZ) sehingga pengentasan kemiskinan terkesan gerakan parsial dan bukan gerakan bersama.

Setelah menempuh proses yang cukup panjang, pada 25 November 2011 secara resmi pemerintah mengundangkan Undang-Undang Nomor 23 Tahun 2011 tentang Pengelolaan Zakat dan mencabut Undang-Undang Nomor 38 Tahun 1999. Dalam Undang-UndangZakatbarupengelolaanzakatmenjadi kewenangan negara, masyarakat dapat mengelola apabila mendapat izin dari pemerintah. Ada beberapa hal yang menarik dari Undang-Undang Pengelolaan Zakat yang baru, khususnya berkaitan dengan relasi BAZ dan LAZ dalam pengelolaan zakat. Pasal 5 ayat (1) menyatakan bahwa untuk melaksanakan pengelolaan zakat, Pemerintah membentuk BAZNAS. Secara eksplisit, peran BAZNAS ditegaskan kembali dalam Pasal 6 yang menyatakan bahwa BAZNAS merupakan lembaga yang berwenang melakukan tugas pengelolaan zakat secara nasional. Eksistensi LAZ dalam pengelolaan zakat masih diakui dalam Undang-Undang. Sekalipun perannya dianggap dikerdilkan oleh praktisi pengelolaan zakat. Pasal 17 menyatakan untuk membantu BAZNAS dalam pelak- 
sanaan pengumpulan, pendistribusian, dan pendayagunaan zakat, masyarakat dapat membentuk LAZ.

Melalui beberapa pasal di atas, dua lembaga ini yang sebelumnya berdiri sejajar, kini berubah. LAZ sekarang menjadi pendukung BAZNAS yang berperan sebagai koordinator. Atau dengan kata lain, BAZ berfungsi sebagai operator sekaligus pengawas pengelolaan zakat, sedangkan LAZ hanya merupakan operator zakat yang wajib bertanggungjawab kepada BAZNAS sebagaimana diatur dalam Pasal 19. Syaratsyarat pembentukan LAZ juga mengalami perubahan, sebagaimana diatur dalam Pasal 18 Undang-Undang Pengelolaan Zakat yang baru. Beberapa poin yang menarik dicermati yaitu, LAZ harus terdaftar sebagai organisasi kemasyarakatan Islam yang mengelola bidang pendidikan, dakwah, dan sosial; mendapat rekomendasi dari BAZNAS; dan memiliki pengawas syariat. Syarat-syarat ini memiliki perbedaan yang signifikan jika dibandingkan dengan syarat-syarat pendirian LAZ yang diatur dalam Keputusan Menteri Agama Republik Indonesia Nomor 373 Tahun 2003. Rekomendasi bukan lagi berasal Forum Zakat, melainkan wewenang BAZNAS untuk memberikan ijin operasi terhadap LAZ.

Selain itu, apa yang digagas oleh Mukhtar Zarkasyi menjadi kenyataan. Salah satu syarat mendirikan LAZ adalah berafiliasi dengan salah satu ormas Islam yang ada. Hal ini menimbulkan pesoalan baru, bagaimana dengan sejumlah LAZ, seperti Dompet Dhuafa Republika, Yayasan Dana Sosial alFalah, Rumah Zakat Indonesia yang besikap netral, tidak berafiliasi dengan ormas apapun sejak didirikan. Dalam Pasal 43 ayat (3) dan ayat (4) disebutkan bahwa LAZ yang telah dikukuhkan oleh menteri sebelum Undang-Undang pengelolaan zakat yang baru berlaku tetap diakui, namun dalam jangka waktu 5 tahun mereka wajib menyesuaikan dengan syarat-syarat yang baru. Dengan jumlah LAZ yang ada dan ormas Islam yang diakui, apakah mungkin pengelolaan potensi zakat di Indonesia akan maksimal. Terlebih masih ada rasa sentimen di antara ormas-ormas Islam di Indonesia. Hal ini tentu akan mengganggu kinerja LAZ dalam memberdayakan mustahik, jika tidak ada Peraturan Pemerintah sebagai pelaksana teknis Undang-Undang.

Pasal 38 dan pasal 41 tentang ancaman sanksi bagi masyarakat yang mengelola zakat tapi tidak memiliki izin dari pemerintah juga memicu kontroversi di masyarakat. Dari dua pasal ini diketahui bahwa setiap orang yang menyelenggarakan pengelolaan zakat, tanpa ada izin dari pemerintah dipidana dengan pidana penjara maksimal 1 (satu) tahun atau denda maksimal Rp. 50.000.000. Dengan merujuk pada keumuman teks, tidak menutup kemungkina ta'mir masjid, kiai, pondok pesantren, muzakki yang tidak mengantongi izin dari pemerintah untuk mengambil atau mendistribusikan zakat terkena pidana. Jika penjelasan dan petunjuk pelaksanaannya tidak jelas, bisa berakibat menjadi kontra produktif dan mematikan sebagian potensi perkembangan zakat yang sudah baik selama ini.

Menurut Rohadi Abdul Fatah selaku Direktur Pemberdayaan Zakat Kementerian Agama RI, menyatakan bahwa LAZ harus berbasis organisasi kemasyarakatan (ormas) Islam dan berbadan hukum, untuk memastikan keamanan aset umat yang dikelola. Pemerintah memberikan jaminan bahwa LAZ yang sudah ada tidak akan dihapus. Posisi LAZ dalam Undang-Undang tidak boleh diartikan secara sempit dan letterlijk, tetapi harus dimaknai dalam konteks keharusan berkoordinasi. Pemerintah berperan dalam pembinaan, regulasi dan pengawasan, serta motivasi dan fasilitatif, sedangkan BAZNAS sebagai organisasi pemerintah non-struktural yang akan mengkoordinir pengelolaan zakat secara nasional. Hal ini akan memudahkan muzakki membayar zakat, serta memudahkan mustahik memperoleh haknya. ${ }^{24}$ Didin Hafidhuddin menambahkan bahwa Undang-Undang tidak memarginalkan peran LAZ dan mengunggulkan BAZNAS. Tugas BAZNAS sebenarnya hanya dua, yakni sebagai operator terbatas dan koordinator. Sedangkan yang lain diberikan pada LAZ. ${ }^{25}$

Munculnya lembaga-lembaga amil zakat menampilkan sebuah harapan akan tertolongnya kesulitan hidup kaum dhuafa. Masalah kemiskinan dan pengangguran yang terjadi di Indonesia akan terselesaikan. Namun, menurut Umratul Khasanah, harapan ini akan sulit tercapai jika lembaga amil zakat tidak memiliki orientasi dalam pemanfaatan dana zakat yang tersedia. Jika merujuk pada sejarah Islam, dana zakat memiliki arti yang signifikan, karena peran serta khalifah. Lembaga-lembaga amil zakat yang ada di bawah satu atap koordinasi dan bersinergi satu sama lain melalui bantuan negara. ${ }^{26}$ Dana yang telah terkumpul harus didistribusikan sesuai sasaran yang telah direncanakan sebelumnya. Untuk menjaga kepercayaan publik, dana tersebut harus dikelola ber-

\footnotetext{
24 Untung Kasirin, Notulensi Seminar Zakat dengan tema "Masa Depan Zakat Indonesia Pasca UU Zakat Baru: Peluang dan Tantangan”, (Online) (www. imz.or.id, diakses tanggal 18 Mei 2012)

25 Afriza Hanifa, Penguatan BAZ pengerdilan LAZ?, (Online) (www.republika. co.id, tanggal 18 Mei 2012)

26 Umratul Khasanah, Manajemen, h. 60
} 
dasakan proses pertanggungjawaban agar para sumber dana yakin bahwa zakat yang dikeluarkan, disalurkan dan dimanfaatkan sesuai ketentuan Syariah. ${ }^{27}$

\section{Munculnya Lembaga Amil Zakat di Indonesia}

Menurut Adiwarman Karim dan A. Azhar Syarief, ${ }^{28}$ munculnya sejumlah LAZ di Indonesia terdiri dari faktor penarik seperti: (1) Semangat Menyadarkan Umat (Spirit of Consciousness). LAZ menjadi motor dalam penyadaran umat akan urgensi zakat yang seharusnya menjadi tugas negara. Hal ini didasari atas kenyataan bahwa Indonesia bukanlah negara Islam yang bisa memaksa bahkan memerangi mereka yang tidak mau membayar zakat. (2) Semangat Melayani Secara Profesional (Spirit of Professional Services). Kepercayaan yang tinggi terhadap lembaga yang dikelola secara profesional pada gilirannya akan membuat para muzakki semakin gemar berzakat. Implikasinya, potensi zakat yang dapat dikumpulkan akan semakin besar dan persoalan kesenjangan ekonomi akan mudah diatasi. (2) Semangat Berinovasi Membantu Mustahik (Spirit of Inovation). Kemajuan sebuah lembaga bergantung pada inovasi. Tanpanya, suatu lembaga hanya akan melakukan pekerjaan yang sama dari waktu ke waktu. Berdasarkan hal ini, banyak LAZ yang memiliki program-program unik dalam memikat hati muzakki. Misalnya, Rumah Zakat Indonesia dengan program Super Qurban-nya. (3) Semangat Memberdayakan Masyarakat (Spirit of Empowering). Munculnya LAZ maupun BAZ di Indonesia, menandakan masih banyaknya orangorang yang peduli terhadap derita yang dialami oleh lingkungan sekitar kita. Sehingga hal ini perlu diapresiasi positif.

Sedangkan faktor pendorong terbentuknya LAZ antara lain: (1) Potensi Penghimpunan Dana Zakat Yang Besar (Huge Market Potential). Potensi zakat yang dikemukakan oleh beberapa lembaga di atas, berapapun nilainya, bukanlah angka yang kecil, jika semua dana itu bisa terkumpul dan dikelola oleh lembaga yang profesional dan didistribusikan secara produktif, maka bisa dibayangkan besarnya manfaat yang diperoleh masyarakat kurang mampu agar bisa bangkit dari keterpurukannya. (2) Regulasi Yang Mulai Mendukung (Friendly Regulation). Meskipun pengelolaan zakat pada awalnya hanya diatur dengan keputusan dan instruksi menteri, setidaknya

\footnotetext{
27 Umratul Khasanah, Manajemen, h. 61

28 Adiwarman Karim dan A. Azhar Syarief, "Fenomena Unik Di Balik Menjamurnya Lembaga Amil Zakat (LAZ) Di Indonesia”, (Online) (www. imz.or.id, diakses tanggal 18 Mei 2012)
}

negara telah memberikan payung hukum terhadap pelaksanaan ajaran agama Islam di Indonesia. Dukungan terhadap institusi pengelola zakat dikuatkan dan diperjelas melalui Undang-Undang Nomor 38 Tahun 1999 jo. Undang-Undang Nomor 23 Tahun 2011 tentang Pengelolaan Zakat. (3) Infrastruktur IT yang menunjang (IT Infrastructure). Untuk menanggulangi penumpukan aliran dana zakat, infaq, shadaqoh pada satu orang, Direktorat Pemberdayaan Zakat Kementerian Agama telah membangun sistem informasi zakat nasional yang berbasis teknologi informasi sehingga dapat diketahui data base mustahik dan muzakki secara menyeluruh serta hasil penghimpunan dan penyaluran zakat, infak dan shadaqah dapat dimonitor setiap saat. Melalui teknologi yang ada, muzakki dapat menyalurkan atau mengetahui laporan pendistribusian zakat, infaq maupun shadaqah yang dilakukan oleh LAZ secara online kapanpun dan dimanapun. (4) Tingkat Kesadaran Masyarakat Yang Makin Meningkat (Awareness Increasing). Menarik jika kita melihat kesadaran masyarakat yang semakin meningkat terhadap pentingnya berzakat. Survei PIRAC melaporkan tingkat kesadaran muzakki meningkat dari 49,8\% di tahun 2004 menjadi 55\% di tahun 2007. Hal ini berarti dalam kurun waktu 3 tahun terjadi peningkatan sebesar 5,2\% kesadaran berzakat dalam masyarakat, jika 5,2\% itu dikalikan dengan populasi muzakki di Indonesia, maka terdapat lebih dari 29 juta keluarga sejahtera yang akan menjadi warga sadar zakat. Akan tetapi, diperkirakan hanya ada sekitar 12 - 13 juta muzakki yang membayar zakat via LAZ, berarti masih ada lebih dari separuh potensi zakat yang belum tergarap oleh LAZ.

\section{Peran dan Fungsi Lembaga Amil Zakat}

Lembaga Amil Zakat diakui oleh Undang-Undang sebagai bentuk partisipasi masyarakat dalam pengelolaan dana zakat, infaq, dan shadaqah di Indonesia. Pasal 1 poin 1 Undang-Undang Nomor 38 Tahun 1999 menyebutkan bahwa pengelolaan zakat adalah kegiatan perencanaan, pelaksanaan dan pengawasan terhadap pengumpulan dan pendistribusian serta pendayagunaan zakat. Berdasarkan ketentuan di atas terdapat tiga peran yang dimainkan dalam pengelolaan zakat, yaitu operator, pengawas dan regulator. Peran yang dimainkan LAZ hanya sebagian kecil, yaitu sebagai operator. Sedangkan peran-peran yang lain menjadi kewenangan pemerintah. Peran ini diatur dalam Pasal 8 yang menyatakan badan amil zakat sebagaimana dimaksud pada Pasal 6 dan 
lembaga amil zakat sebagaimana dimaksud pada Pasal 7 mempunyai tugas pokok mengumpulkan, mendistribusikan dan mendayagunakan zakat sesuai dengan ketentuan agama.

LAZ dengan BAZ memilikiperan dan kedudukan yang sama, yaitu membantu pemerintah mengelola zakat. Keduanya berdiri sendiri dalam melakukan aset zakat. Keberadaan LAZ maupun BAZ harus mampu mewujudkan tujuan besar dilaksanakannya pengelolaan zakat, seperti meningkatkan kesadaran masyarakat dalam penunaian zakat, meningkatkan fungsi pranata keagamaan untuk mewujudkan kesejahteraan masyarakat dan keadilan sosial, serta meningkatkan hasil guna dan daya guna zakat. ${ }^{29}$

Undang-Undang Nomor 23 Tahun 2011 tentang Pengelolaan Zakat yang baru, membawa perubahan terhadap peran LAZ dalam menjalankan fungsi pengelolaan zakat. Pasal 17 yang menyatakan bahwa untuk membantu BAZNAS dalam pelaksanaan pengumpulan dan pendistribusian, dan pendayagunaan zakat, masyarakat dapat membentuk LAZ.

Jika dalam Undang-Undang yang lama posisi keduanya dipandang sejajar dan seimbang dalam menjalankan fungsi pengelolaan zakat, dalam UndangUndang yang baru ini peran LAZ menjadi dikerdilkan dan diposisikan sebagai subordinat dari BAZ yang dibentuk oleh pemerintah. Pergeseran inilah yang ditentang oleh LAZ-LAZ yang tergabung dalam Forum Zakat, bahkan ada wacana untuk melakukan judicial review kepada Mahkamah Konstitusi, meskipun instrumen yang keberlakuannya, yaitu Peraturan Pemerintah diberi tenggat satu tahun..$^{30}$ Adapun perbandingan skema hubungan peran antara BAZ dan LAZ dalam Undang-Undang 38 Tahun 1999 maupun Undang-Undang Nomor 21 Tahun 2011 sebagai berikut:
Skema relasi BAZ dan LAZ dalam

UU. 38 Tahun 1999

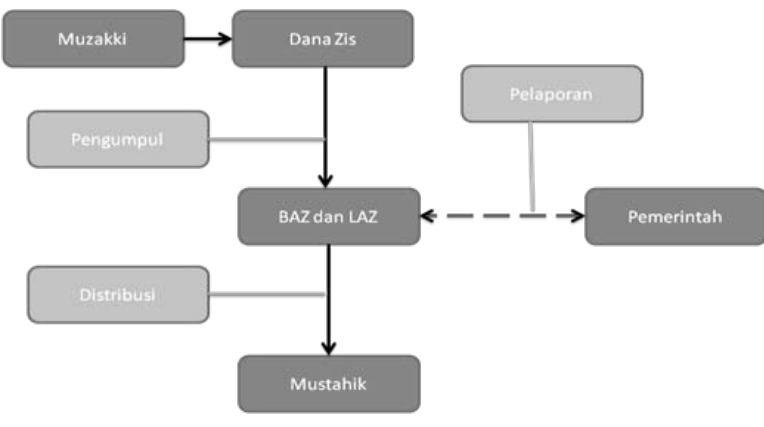

[Back]

Skema relasi BAZ dan LAZ dalam

UU. 21 Tahun 2011

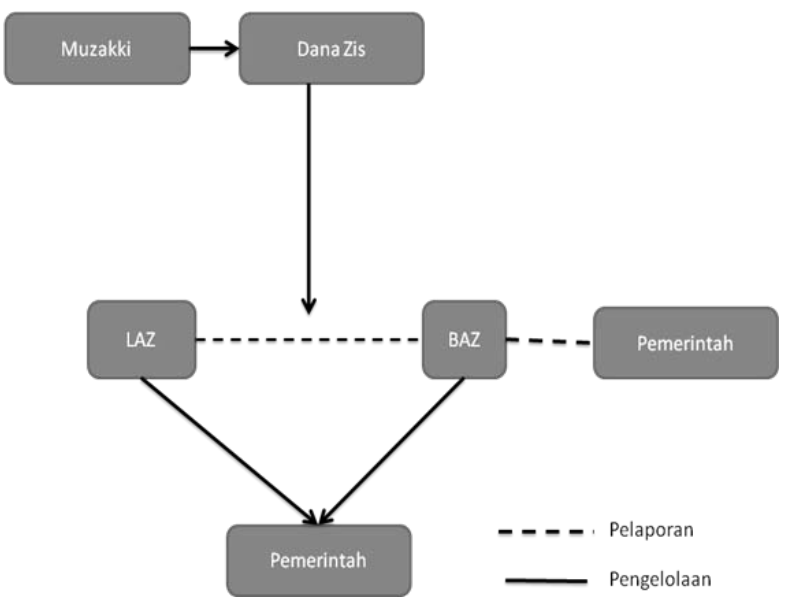

\section{Optimalisasi Peran Lembaga Amil Zakat}

Indonesia sebagai negara terbesar penduduk muslimnya di dunia mempunyai peluang yang sangat besar untuk meningkatkan kesejahteraan rakyatnya lewat zakat. Namun demikian menurut penelitian yang dilakukan oleh Eri Sudewo bahwa secara umum zakat di Indonesia belum banyak berdampak pada peningkatan kualitas kehidupan kaum miskin. Hal ini disebabkan karena pengelolaan zakat oleh lembaga amil zakat, baik Badan Amil Zakat (BAZ) maupun Lembaga Amil Zakat (LAZ) kebanyakan masih menggunakan manajemen tradisional. Oleh karena itu menurutnya untuk meningkatan kualitas kehidupan kaum miskin, maka disarankan untuk meninggalkan 15 tradisi yang selama ini berkembang di BAZ dan LAZ tersebut, kemudian menerapkan 4 prinsip dasar.
29 Fakhruddin, Fiqh, h. 253-254

30 Abdul Mukthie Fadjar, Menguji Konstitusionalitas Undang-Undang Nomor 23 Tahun 2011 tentang Pengelolaan Zakat, makalah disampaikan dalam forum kuliah umum dan konsultasi publik "Mengkritisi UU 23/2011", tanggal 12 April 2012 (Malang, Universitas Brawijaya,2012), h. 1 
Kelima belas tradisi dimaksud adalah: (1) anggapan sepele, bahwa zakat merupakan bantuan yang kemudian membentuk paradigma bahwa bantuan adalah pekerjaan sosial semata sehingga tidak perlu mendapat perhatian ekstra. (2) kelas dua, dimana zakat tidak perlu dikelola dengan serius, akan tetapi cukup dengan sisa-sisa tenaga saja, (3) tanpa manajemen akan tetapi pengelolaan zakat kebanyakan menggunakan intuisi sehingga pengeloalaan zakat berjalan sesuai dengan persepsi masing-masing, (4) tanpa perencanaan karena bersifat bantuan, maka kapanpun bisa dijalankan, (5) oleh karena tidak adanya perencanaan, maka pembentukan struktur organisasi seringkali tumpang tindih, (6) tanpa fit and proper test karena hal ini merupakan suatu hal yang sangat muluk bagi pengelolaan zakat yang bersifat bantuan tersebut, sehingga dengan demikian menimbulkan (7) kaburnya batasan antara wewenang dan tanggung jawab, (8) ikhlas tanpa imbalan karena anggapan bahwa hal ini meruapakan pekerjaan sosial, akan tetapi kemudian menimbulkan pengelolaan zakat (9) dikelola dengan paruh waktu, (10) lemahnya SDM, (11) bukan pilihan, hal ini akan berpengaruh besar pada kondisi kejiwaan yang bersangkutan dan lembaga itu sendiri, (12) lemahnya kreatifitas yang menyebabkan program-program yang dilahirkan tidak inovatif, (13) tidak ada monitoring dan evaluasi, (14) tidak disiplin, (15) kepanitiaan tidak ada perencanaan kegiatan yang sifatnya sporadis dan berjangka pendek. ${ }^{31}$

Kelima belas persoalan yang dikemukakan, Eri Sadewo masih dapat dijumpai dalam kehidupan sehari-hari. Dalam suatu kepengurusan LAZ misalnya, pengelola zakat masih "nyambi" dengan pekerjaan yang lain, seperti pendidik, pedagang, atau perkerjaan lain dengan alasan memenuhi kebutuhan ekonomi agar ia mampu beramal secara ikhlas pada saat mengelola asset zakat. Padahal, tenaga yang digunakan pada saat mengurus LAZ adalah sisa-sisa yang digunakan dalam pekerjaan ekonomis yang ia lakukan seharihari. Hal ini membuat penggalian potensi zakat tidak maksimal.

Sedangkan 4 prinsip dasar yang dikembangkan,: Pertama, prinsip rukun Islam yang dibedakan menjadi dua, yaitu rukun pribadi dan rukun masyarakat. Zakat merupakan rukun masyarakat, yang artinya zakat merupakan bentuk ibadah vertikal kepada Allah sekaligus merupakan ibadah yang horizontal, karena menyangkut kebutuhan manusia. Menurut Sadewo, sifat dan karakter masing-masing ibadah dapat didekati

\footnotetext{
31 Eri Sudewo, Manajemen Zakat, Tinggalkan 15 Tradisi, Terapkan 4 Prinsip Dasar, (Jakarta: IMZ, 2004), h. 11-20.
}

menggunakan prinsip $5 \mathrm{~W}+1 \mathrm{H}$. Dalam persoalan how, dalam ibadah zakat pengaturannya diserahkan kepada manusia. Sebab, sifat dan kebutuhan setiap manusia berbeda. Misalnya, ijab kabul atau penyerahan zakat dari muzakki dengan amil secara langsung tidak lagi banyak terjadi. Sebab, melalui perkembangan teknologi muzakki dapat menyalurkan dananya melalui mesin ATM atau transfer via bank. Hal ini menunjukkan bahwa kepercayaan muzakki terhadap amil meningkat, tanpa harus bertatap muka dengannya. Selain itu, kesalehan dalam ibadah zakat merupakan keberhasilan membentuk suatu masyarakat yang saling membantu berdasarkan kesadaran.

Kedua, prinsip moral. Dalam pengelolaan zakat, para âmil dituntut memiliki sifat jujur, amanah, siddiq, tanggung jawab, adil, kasih, gemar menolong, dan tabah. Menurut Sadewo, kejujuran menjadi kata kunci utama, sebab pengelolaan zakat belum dikontrol oleh lembaga resmi yang dapat memberikan sanksi, muzakki tidak tahu kemana zakatnya disalurkan, masyarakat seolah tidak punya hak memantau pengelolaan zakat. Ketiga, prinsip lembaga. Ada beberapa prinsip kelembagaan yang harus dimiliki oleh lembaga zakat agar bisa dipercaya oleh donatur dan masyarakat, yaitu: figur yang tepat, non-politik, non-golongan, independen, dan netral obyektif. Keempat, prinsip manajemen. Terdapat dua gaya dalam manajemen, yaitu management by result dan management by process. Management by result mementingkan hasil sehingga dengan demikian dia berjangka pendek, sedangkan management by process lebih mementingkan proses sehingga berjangka panjang. Menurut Eri Sudewo, lembaga zakat lebih tepat menggunakan management by process. Hal ini disebabkan karena nilai yang menjadi landasan utama lembaga zakat menjadi pas dengan karakter dasar management by process, karena tujuan lembaga zakat adalah memberdayakan masyarakat. Untuk menuju pada pemberdayaan yang dimaksud dibutuhkan waktu yang cukup. Di samping itu, dibutuhkan pula partisipasi dan pengertian muzakki, mustahiq, mitra kerja, pemerintah, dan masyarakat. ${ }^{32}$

Prinsip pertama, dalam pandangan penulis sudah teraplikasikan. Sudah banyak LAZ yang berinovasi dalam melakukan penggalian potensi zakat, salah satunya memanfaatkan perkembangan teknologi informasi. Hampir semua LAZ memiliki website dan jejaring sosial. Dengan demikian, masyarakat dapat mengakses program dan laporan pendayagunaan

\footnotetext{
32 Eri Sudewo, Manajemen Zakat, h. 30-57.
} 
zakat, infaq, shadaqah untuk kepentingan mustahiq. Namun, Prinsip tidak berafiliasi dengan golongan tertentu, saat ini tengah menghadapi tantangan. Sebab, hal itu justru menjadi syarat utama pendirian LAZ dalam Undang-Undang Pengeloaan Zakat yang baru. Kekhawatiran ini belum sepenuhnya terbukti hingga dikeluarkannya Peraturan Pemerintah sebagai aturan penjelas sekaligus aturan teknis.

\section{Kesimpulan}

Lembaga Amil Zakat (LAZ) sebagai wujud partisipasi masyarakat, baik dalam Undang-Undang Nomor 38 Tahun 1999 maupun Undang-Undang Nomor 23 Tahun 2011 tentang Pengelolaan Zakat berperan sebagai operator yang berfungsi melakukan pengelolaan terhadap aset zakat, sekalipun posisinya berada di bawah BAZNAS dalam Undang-Undang

\section{DAFTAR PUSTAKA}

Abdul Mukthie Fadjar, Menguji Konstitusionalitas Undang-Undang Nomor 23 Tahun 2011 tentang Pengelolaan Zakat, makalah disampaikan dalam forum kuliah umum dan konsultasi publik "Mengkritisi UU 23/2011", tanggal 12 April 2012. Malang, Universitas Brawijaya, 2012

Abubakar, Irfan dan Bamualim,Chaider S. (ed.).Filantropi Islam dan Keadilan Sosial, Studi tentang Potensi, Tradisi dan Pemanfaatan Filantropi Islam di Indonesia.Jakarta: Center for the Studi of Religion and Cultur, UIN Syarif Hidayatullah, 2006.

Adiwarman Karim dan A. Azhar Syarief, "Fenomena Unik Di Balik Menjamurnya Lembaga Amil Zakat (LAZ) Di Indonesia", (Online) www.imz. or.id, diakses tanggal 18 Mei 2012

Aflah, Noor. Arsitektur Zakat Indonesia Dilengkapi Kode Etik Amil Zakat Indonesia.Jakarta: UIPress, 2009.

Afriza Hanifa, Penguatan BAZ pengerdilan LAZ?, (Online) www.republika.co.id, tanggal $18 \mathrm{Mei}$ 2012

Ahmad Juwaini, Mencermati dan Menyikapi UndangUndang Nomor 23 Tahun 2011, (Online) www. forumzakat.net, diakses tanggal 18 Mei 2012

al-Qardhawi, Yusuf. Dauru al-Zakat fi 'ilaj almusykilat al-Istishadiyah, terj. Sari Nurilita. Spektrum Zakat dalam Membangun Ekonomi Kerakyatan. Jakarta: Zikrul Hakim, 2005.
Pengelolaan Zakat yang baru. Adapun fungsi LAZ yang paling utama adalah menumbuhkan kesadaran muzakkiuntuk menyalurkan danaZIS kepada LAZ dan mendayagunakannya untuk kepentingan Mustahik, agar dikemudian hari mereka mampu menghadapi persoalan sosio-ekonomi secara mandiri.

Untuk meningkatkan peran dan fungsi LAZ perlu dikembangkan empat prinsip, yaitu prinsip rukun iman, prinsip moral, prinsip manajemen, dan prinsip lembaga. Prinsip moral, rukun iman, lembaga, berfungsi meningkatkan kepercayaan publik, khususnya muzakki untuk menyalurkan zakat, infaq, shadaqahnya kepada LAZ. Sedangkan prinsip menajemen berfungsi memberdayakan para mustahik, sehingga mereka dapat berubah menjadi muzakki dikemudian hari.

Anshori, Abdul Ghofur. Hukum dan Pemberdayaan Zakat.Yogyakarta: Pilar Media, 2006.

Badan Amil Zakat Nasional, Penerimaan dan Penyaluran Tahun 2011, (Online) www.baznas. or.id, diakses tanggal 17 Mei 2012

Badan Pusat Statistik, Jumlah Penduduk Miskin Indonesia www.bps.go.id, diakses tanggal 17 Mei 2012

Eri Sudewo, Manajemen Zakat, Tinggalkan 15 Tradisi, Terapkan 4 Prinsip Dasar, Jakarta: IMZ, 2004

Fakhruddin, "Rekontruksi Paradigma Zakat: Sebuah Ikhtiar Untuk Pemberdayaan Mustahiq", Makalah disampaikan dalam international guest lecture " Manajemen Zakat Kontemporer Malaysia-Indonesia, tanggal 10 Maret 2012 Malang: Universitas Islam Negeri Maulana Malik Ibrahim Malang, 2012.

Fakhruddin. Figh dan Manajemen Zakat di Indonesia. Malang: UIN-Malang Press, 2008.

Hasan, M. Ali. Zakat dan Infak Salah Satu Solusi Mengatasi Problema Sosial di Indonesia. Jakarta: Kencana, 2006.

Khasanah, Umratul. Manajemen Zakat Modern Instrumen Pemberdayaan Ekonomi Umat. Malang: UIN-Malang Press, 2010.

Multifiah, Peran Zakat, Infaq, dan Shadaqah terhadap Kesejahteraan Rumah Tangga Miskin, Jurnal Ilmu-Ilmu Sosial (Social Sciences), Volume 21 Nomor 1, Februari,2009. 
34 Jurisdictie, Jurnal Hukum dan Syariah, Volume 3, Nomor 1, Juni 2012, hlm 24-34

Sudirman. Zakat dalam Pusaran Arus Modernitas. Malang: UIN-Malang Press, 2007.

Suprayogo,Imam.Zakat, Modal Sosial, dan Pengentasan Kemiskinan, dalam Didin Hafidhuddin. Dkk. The Power of Zakat Studi Perbandingan Pengelolaan Zakat Asia Tenggara.Malang: UIN-Malang Press, 2008.

Undang-Undang Nomor 23 Tahun 2011 tentang Pengelolaan Zakat Lembaran Negara Tahun 2011 Nomor 115 .
Undang-Undang Nomor 38 Tahun 1999 tentang Pengelolaan Zakat Lembaran Negara Tahun 1999 Nomor 164 Tambahan Lembaran Negara Nomor 3885.

Untung Kasirin, Notulensi Seminar Zakat dengan tema "Masa Depan Zakat Indonesia Pasca UU Zakat Baru: Peluang dan Tantangan”, (Online) www.imz.or.id, diakses tanggal 18 Mei 2012.

Wibisono,Yusuf. Ironi Undang-Undang Zakat, (Online) www.republika.co.id, diakses tanggal 17 Mei 2012. 